\title{
An initial approach to e-government acceptance and use: A literature analysis of e-Government acceptance determinants
}

Conference Paper · June 2017

DOI: 10.23919/CISTI.2017.7976044

CITATION

1

5 authors, including:

José Luis Bandeira Rodrigues Martins

Universidade de Trás-os-Montes e Alto Douro 76 PUBLICATIONS 206 CITATIONS

SEE PROFILE

Ramiro Gonçalves

Universidade de Trás-os-Montes e Alto Douro 177 PUBLICATIONS 420 CITATIONS

SEE PROFILE
READS

35
Universidade de Trás-os-Montes e Alto Douro 50 PUBLICATIONS 90 CITATIONS

SEE PROFILE

Manuel Au-Yong Oliveira

University of Aveiro 31 PUBLICATIONS 86 CITATIONS

SEE PROFILE

Some of the authors of this publication are also working on these related projects:

Management Information Systems View project

DOUROTUR, TURISMO E INOVAÇÃO TECNOLÓGICA NO DOURO - Task 4 "Marketing digital e novas tecnologias para desenvolvimento do turismo no Douro View project 


\title{
An Initial Approach to e-Government Acceptance and Use
}

\author{
A literature analysis of e-Government acceptance determinants
}

\author{
Soraia Nunes ${ }^{\mathrm{a}}$, José Martins ${ }^{\mathrm{a}, \mathrm{b}}$, Frederico Branco ${ }^{\mathrm{a}, \mathrm{b}}$, Ramiro Gonçalves ${ }^{\mathrm{a}, \mathrm{b}}$, Manuel Au-Yong-Oliveira ${ }^{\mathrm{c}}$ \\ ${ }^{a}$ University of Trás-os-Montes e Alto Douro, Vila Real, Portugal \\ ${ }^{b}$ INESC TEC and UTAD, Vila Real, Portugal \\ c GOVCOPP, Department of Economics, Management, Industrial Engineering and Tourism, University of Aveiro, Aveiro, \\ Portugal \\ soraia nunes13@,hotmail.com, jmartins@utad.pt, fbranco@utad.pt, ramiro@utad.pt, mao@ua.pt
}

\begin{abstract}
Information technology has become one of the core elements of electronic government (e-Government) and should figure prominently in future governance. E-Government services, through electronic means, should provide a more costeffective and convenient way for citizens to interact with government, however their adoption is still far from a satisfactory level. The study herein has examined research on the adoption of e-Government services. Using data obtained from previous research, this article identifies the variables that contribute to the adoption of e-Government by citizens and the model created is presented. Overall, this study concludes that eGovernment has been adopted by many governments, but it is still at an early stage, and there are still barriers to its more widespread adoption in society.
\end{abstract}

Keywords - e-Government; adoption, technology.

\section{INTRODUCTION}

Information technology (IT) has become one of the core elements of managerial reform, and electronic government (eGovernment) may figure prominently in future governance. IT has opened up many new possibilities for improving internal managerial efficiency and the quality of public service delivery to citizens. E-Government is a fundamental element in the modernization of any government, serving as a means towards enhancing transparency, accountability, and good governance; making the government more results-oriented, efficient and citizen-centered; and enabling citizens and businesses to access government services and information as efficiently and as effectively as possible through the use of the internet and other channels of communication [1]. The use of IT in the government sector offers great opportunities for enhancing service quality and efficiency while trimming down on governmental expenses. An effective and operational e-Government facilitates a better and more efficient delivery of information and services to citizens. At the same time productivity is promoted amongst civil servants, while encouraging the participation of citizens in government, providing a means for citizens to feel and effectively be more empowered [2].

\section{THEORETICAL FRAMEWORK}

\section{A. e-Government Conceptualization}

E-Government is a generic term for web-based services of agencies of local, state and federal governments. In e-
Government, the government uses information technology and particularly the Internet to support government operations, engage citizens, and provide government services. The interaction may be in the form of obtaining information, filings, or making payments, and a host of other activities via the World Wide Web [3] [4] [5]. E-Government is defined by other sources as follows:

According to the European Commission (EC, 2016), eGovernment uses digital tools and systems to provide better public services to citizens and businesses. Effective eGovernment can provide a wide variety of benefits including more efficiency and savings for governments and businesses, increased transparency, and greater participation of citizens in political life. ICTs are already widely used by government bodies, as occurs in enterprises, but eGovernment involves much more than just the tools. It also involves rethinking organizations and processes, and changing behavior so that public services are delivered more efficiently to people. The European Commission (www.ec.europa.eu) reports that: "Implemented well, eGovernment enables citizens, enterprises and organizations to carry out their business with government more easily, more quickly and at a lower cost."

A World Bank (www.worldbank.org) definition (AOEMA report) is as follows: "E-Government refers to the use by government agencies of information technologies (such as Wide Area Networks, the Internet, and mobile computing) that have the ability to transform relations with citizens, businesses, and other arms of government. These technologies can serve a variety of different ends: better delivery of government services to citizens, improved interactions with business and industry, citizen empowerment through access to information, or more efficient government management. The resulting benefits can be less corruption, increased transparency, greater convenience, revenue growth, and/or cost reductions."

A United Nations (www.unpan.org) definition (AOEMA report) is as follows: "E-Government is defined as utilizing the Internet and the world-wide-web for delivering government information and services to citizens. " 
A Global Business Dialogue on Electronic Commerce GBDE (www.gbde.org) definition (AOEMA report) is: "Electronic government (hereafter e-Government) refers to a situation in which administrative, legislative and judicial agencies (including both central and local governments) digitize their internal and external operations and utilize networked systems efficiently to realize better quality in the provision of public services."

A definition of the Working Group on E-Government in the Developing World (www.pacificcouncil.org) is as follows: "E-Government is the use of information and communication technologies (ICTs) to promote more efficient and effective government, facilitate more accessible government services, allow greater public access to information, and make government more accountable to citizens. E-Government might involve delivering services via the Internet, telephone, community centers (self-service or facilitated by others), wireless devices or other communications systems.",

While definitions of e-Government by various sources may vary widely, there is a common theme. E-Government involves using information technology, and especially the Internet, to improve the delivery of government services to citizens and businesses. E-Government enables citizens to interact and receive services from governments twenty-four hours a day, seven days a week.

E-Government is in the early stages of development. Most governments have already taken or are taking initiatives offering government services online. However, for the true potential of e-Government to be realized, government needs to restructure and transform its long entrenched business processes.

\section{B. e-Government VS e-Governance}

E-governance is beyond the scope of e-Government. While e-Government is defined as a mere delivery of government services and information to the public using electronic means, e-governance allows citizens to have direct participation as constituents in political activities going beyond government and includes E-democracy, E-voting and participating in political activity online. So, most broadly, the concept of E-governance will cover government, citizens' participation, political parties and organizations, parliament and judiciary functions [6]. For many people there is clearly still considerable confusion relative to the explaining of eGovernment and e-governance [7], and for a clear definition between these two concepts, a definition is presented here so that there is no overlap. E-government's focus is on constituencies and stakeholders outside the organization, whether it is the government or public sector at the city, county, state, national, or international levels. On the other hand, e-governance focuses on administration and management within an organization, whether it is public or private, large or small. For a clearer presentation of the concepts these are presented in Table I, in a summary made by the authors.
Table I - Table adapted from E-Government and E-Governance (Palvia \& Sharma [7])

\begin{tabular}{|c|c|c|c|}
\hline & \multicolumn{2}{|c|}{ FOCUS } \\
\hline & & Outside & Inside \\
\hline \multirow{2}{*}{ 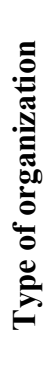 } & $\begin{array}{c}\text { Public Sector } \\
\text { - Government } \\
\text { Agency }\end{array}$ & $\begin{array}{l}\text { E-Government } \\
\text { (Extranet and } \\
\text { Internet) }\end{array}$ & $\begin{array}{l}\text { E-Governance } \\
\text { (Intranet) }\end{array}$ \\
\hline & $\begin{array}{c}\text { Private Sector } \\
\text { - MNCs or } \\
\text { SMEs }\end{array}$ & $\begin{array}{c}\text { Inter- } \\
\text { Organizational } \\
\text { Systems - IOS } \\
\text { like CRM } \\
\text { Systems } \\
\text { (Extranet and } \\
\text { Internet) }\end{array}$ & $\begin{array}{l}\text { E-Governance } \\
\text { (Intranet) }\end{array}$ \\
\hline
\end{tabular}

As shown in Table I, e-Governance proposes to manage organizational resources, a part of human resources, materials, machinery, and capital for both the private and public sector through the use of ICT. The role of eGovernment is that of interaction of a government agency with the external environment.

\section{Benefits and Struggles}

With the advancement of ICT several benefits have been provided to society through the availability of public services and information on portals. It is globally recognized that ICT promotes good governance and clear government. Some benefits recognized by the OECD of ICT [8]: ICTs help improve efficiency in mass processing tasks and public administration; the adopting of a customer focus; ICT can help stakeholders share information and ideas; e-Government helps reduce corruption, increases openness and trust in government, and building trust between governments and citizens is fundamental to good governance; finally, ICT helps to increase transparency and accountability.

Ebrahim \& Irani [9] identify, analyze and summarize barriers into dimensions with practical examples that include: (1) IT infrastructure, (2) security and privacy, (3) IT skills, (4) organizational and (5) operational cost of the adoption of electronic government experience in public sector organizations. They affirm that: "technology itself would not guarantee success with e-government but, it is necessary that any e-government initiative must ensure that it has sufficient resources, adequate infrastructure, management support, capable IT staff, and effective IT training and support".

The authors above identified the following as potential benefits for the adoption of electronic government infrastructure: improvement of the efficiency of public administration operations; cost reduction in the collection and transmission of improved business processes and services.

It can be concluded that despite the potential benefits for the adoption of e-Government, there are a number of barriers which prevent the realization of benefits. 


\section{E-GOVERNMENT ACCEPTANCE AND USE}

\section{A. Acceptance and Use Studies}

The adoption of e-Government by citizens has been increasing, thus becoming an important management tool.

Although the population adopts e-Government services, the interaction rate with governments is skill low, leading to the failure of e-Government initiatives.

One verifies that, according to the articles analysed, there are still articles that talk about the subject of e-Government adoption.

By analysing the evolution of the articles in the period from 2010 to 2017, in the 48 articles one verifies that the year 2014 was the year with the largest number of publications (seven articles) on the subject being studied, one also observing that in the last four years this figure has been declining (Figure1).

So far, the number of articles, in 2017 , is three, but there is a possibility that there will be a rise in the number of articles published on this topic, due to the increasing adoption of e-government by citizens.

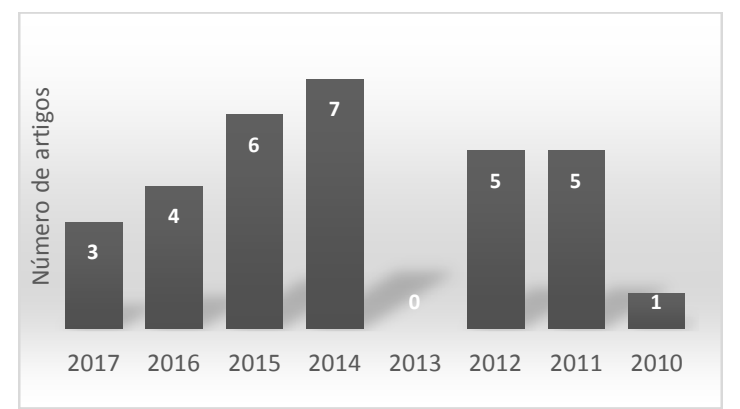

Figure I - Evolution of the number of publications

\section{B. e-Government determinants}

Sixty-seven publications were analysed and filtered based on the title, methodological approach and contribution. Subsequently, only forty-eight articles remained. Through a detailed analysis of the 48 articles (Table II) [7, 10-56], we arrived at the following list of variables, whose association with the acceptance and use of e-Government systems was duly proved. Table II shows for each article the variables identified in the adoption of e-Government.

As concerns Table II a brief description of each variable taken from the analysis of the 48 articles is presented:

- $\quad$ Trust - Is the service offered as promised, that is, in a precise, consistent and timely manner?

- Perceived ease of use - For ease of use to exist, there has to be an ease of interaction between citizens and the website.

- Social Influence - Allows to evaluate the perception of the user in relation to the opinion of other people in the social environment, where the user is inserted, on whether they should or should not use the application.
- Attitude Towards - It is the user's follow-up, whether favourable or not, in relation to using the system.

- Effort Expectancy - Is related to the degree of ease of use of the application. If a negative variable, the user has to strive.

- Performance Expectancy - Is the degree to which an individual believes that using that system will help him or her to attain gains in job performance.

- Compatibility - Services must be agreed upon.

- Internet Skill - The user has the capability and has the knowledge to perform any task on the system.

- Quality - The content and appearance of the information provided must be accurate, concise, and relevant.

- User acceptance - The user must be registered and approved.

- $\quad$ Management Readiness - Refers to the user getting quick results when using the system.

- Sensitivity to cost - The user does not have large expenses when carrying out his or her tasks.

- Usability - Allows the user to use the system in a way that maximizes his or her productivity.

- Computer resource requirement - Allows the user to perform tasks and to predominantly use the professional activities.

- Technical support requirement - It can be understood as a facilitating condition of available resources.

- Security Provision - Refers to a providing of security conditions.

- Services efficiency - Refers to the obtaining of the maximum effectiveness of services, using the least possible commitment, time and other means or resources.

- Perceived Credibility - When one believes one is obtaining quality of resources reliably.

- Internet Accessibility - Allows the user easy access.

- Facility conditions - Indicates the level at which the user believes that the existing organization and infrastructure supports the use of the system.

- Image - The system must have an appealing design.

- Efficiency - Getting results effectively.

- Effectiveness - It indicates to the user the existence of ethics in the service.

- External pressure - The user receives influence from someone.

- Perceived Usefulness - Is the degree to which a user believes that using the system will improve performance. 


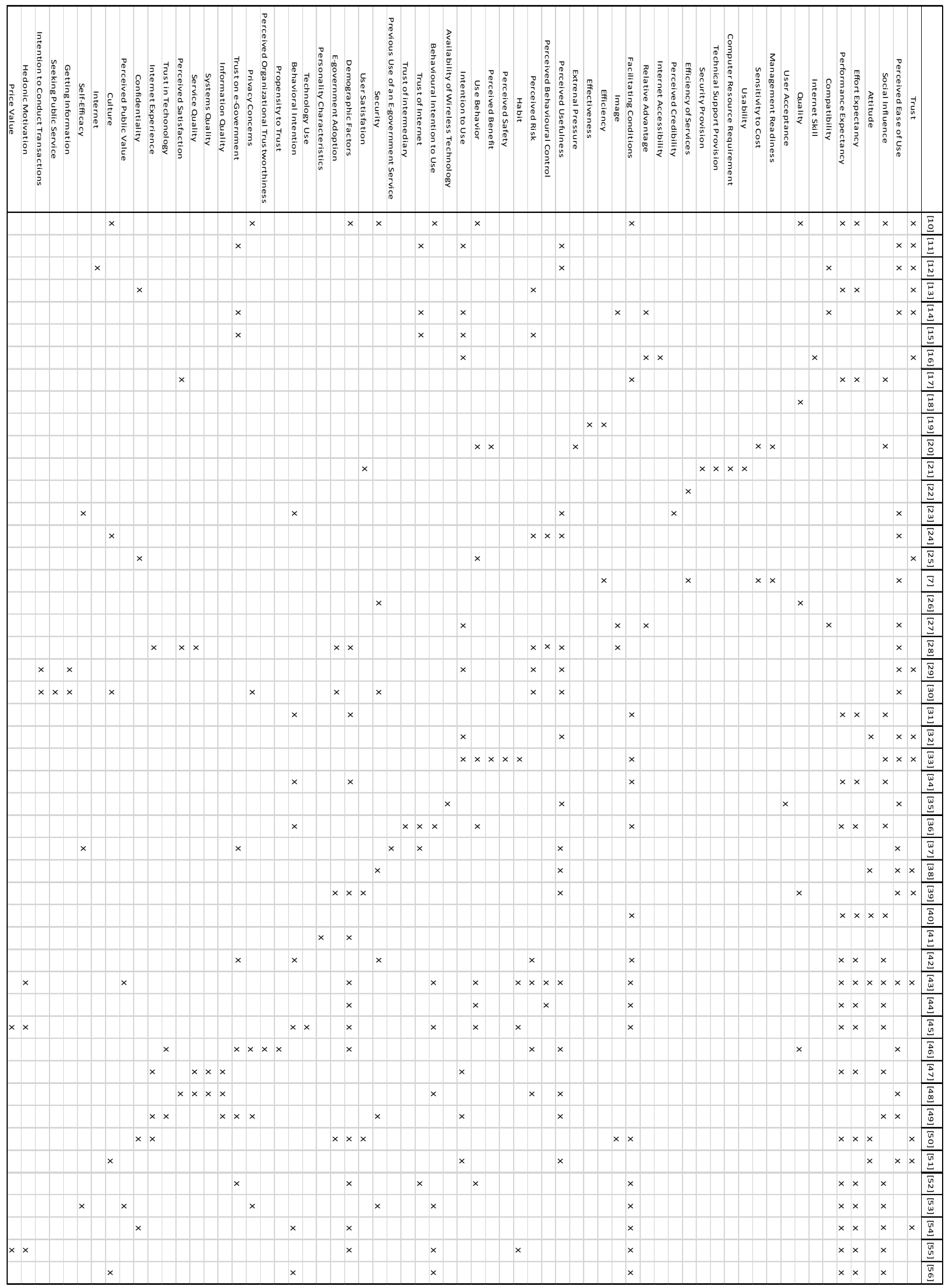


- Perceived risk - It is the risk of possibility of occurrence of loss of personal information.

- Habit - Is the prediction of user behaviour, depending on whether your habit is strong or weak.

- Perceived safety - Feeling secure in tasks.

- Perceived benefit - Can earn money when performing any service.

- Use - The user is able to perform any service.

- Intention to use - The user already has the need to use these resources for the execution of any service.

- Availability of Wireless Technology - Use of the Internet to run your services.

- Behavioural Intention to use - Refers to the strength of the intention to use the system in the future.

- Trust of Internet - The user has confidence in what he or she does, when using the Internet.

- Trust of intermediary - The user must have a minimum trust level in the services.

- Previous use of an e-Government service - Must have had prior use for better service effectiveness.

- Security - Both the user and the system have to be trustworthy.

- User satisfaction - The person feels satisfied and takes pleasure in what her or she does and in obtaining the content.

- Demographic factors - Variables (time, age, etc.) that influence user behaviour.

- E-Government Adoption - Refers to the user's adoption of the services.

- Personality - Refers to the characteristics or state that the user has.

- Technology use - Is the use of services through technology.

- Behavioural Intention - Refers to the degree to which a person has formulated conscious plans to perform or not perform some specified future behaviour(s).

- Propensity to trust - Natural tendency or force that drives a user in a particular direction.

- $\quad$ Perceived organizational trustworthiness - The user has to have confidence in the services of the organization.

- $\quad$ Privacy concerns - The user has privacy problems. A negative variable prevents the user from using a service.

- Trust in e-Government - The user has to feel confident in e-Government.

- Information Quality - The information has to be of good quality and reliable.

- Systems Quality and Service Quality - Importance of the features that the system and service have.
- Perceived Satisfaction - The user has to feel satisfied when performing a service or receiving a certain service.

- Trust in Technology - The user has to feel confident in the technology, because it is through it that a service is performed.

- Internet Familiarity - The user has to be familiar with the Internet for better execution.

- Confidentiality - User data has to be confidential.

- Perceived Public Value - The services have to be legitimate and true.

- Culture - Norms of behaviour, knowledge, habits and beliefs that differentiate one group from another; different groups will have different cultures.

- Internet - Uses the Internet to perform any action and obtain information.

- $\quad$ Self-Efficacy - It is the ability to complete and carry out tasks.

- Getting Information - When performing an action, the user receives information.

- Seeking Public Services - The user when doing something uses public services.

- Intention to Conduct Transactions - Refers to when a user wants to make a transaction.

- Hedonic Motivation - It is the motivation to do something due to the internal satisfaction involved.

- $\quad$ Price Value - This is considered an indicator of the prediction of buying behavior.

\section{RESULTS ANALYSIS AND DISCUSSION}

This study allowed to collect the variables identified by the authors that influenced the citizens' intention to use eGovernment services and their causal relationships with the chosen model. It was verified that the models most used according to the results were TAM (Technology Acceptance Model), UTAUT (Unified Theory of Acceptance and Use of Technology) and UTAUT2 (Unified Theory of Acceptance and Use of Technology 2). It was verified that TAM was the most used model, being present in 18 of the 48 study articles.

TAM is widely used in information systems to study user acceptance of technology.

The TAM [57] has been widely used to explain the usage of information technology (IT). According to the TAM, an individual's intention to use IT, which is often used as the proxy for usage of IT, is determined by attitude, and attitude is determined by two beliefs: perceived usefulness and perceived ease of use. Empirical studies using the TAM have shown that it is a parsimonious and robust model [57].

The UTAUT was formulated by Venkatesh, Morris, Davis, \& Davis [58], and consists of four main concepts: Performance Expectancy (PE), Effort Expectancy (EE), Social Influence (SI), and Facilitating Conditions (FC). These four main concepts are independent variables which 
influence the dependent variables, behavioral and usage. Gender, age, experience, and volunteers of system use have indirectly influenced the dependent variables via the four main concepts.

The UTAUT2 is a theoretic framework which was derived from the TAM and the UTAUT2, and is a powerful predicting framework being proposed by Venkatesh, Thong, \& Xu [45]. The UTAUT2 can effectively explain and analyze people's technology acceptance behaviors.

Table II allows one to see which variables are most present in the studies in the adoption of electronic government services, where eight variables were identified, with the variable trust being the most present in the studies:

(1) Trust;

(2) Perceived Ease of Use;

(3) Social Influence;

(4) Effort Expectancy;

(5) Performance Expectancy;

(6) Facilitating Conditions;

(7) Perceived Usefulness;

(8) Perceived Risk.

Citizens are just beginning to get more meaningful information about the benefits and consequences of using eGovernment services. Thus, the trust variable is important and will have a major impact on the adoption of eGovernment through its influence on trust of the Internet and trust in government.

\section{CONCLUSIONS}

\section{A. Theoretical and Practical Implications}

This study allowed us to extract factors that influence consumer behavior, that is, as concerns the adoption of electronic government services and as a means of perceiving citizens' choices and preferences.

This study also allows to integrate the identification of variables and the models of adoption of electronic government. Research reports repeatedly point out that a lack of confidence makes it difficult for citizens to adopt eGovernment services, hence the constant presence of this variable.

Through this study, the analysis and detailed characterization of variables and the acceptance and use of models of electronic government may be the basis for future research.

\section{B. Future Research}

As regards future work, a focus group will be held, where a group of seven people will be gathered, with the main objective of having a dialogue and checking their reactions on the topic being studied, in order to gather the maximum amount of information. Through the use of this research instrument we will be able to construct a novel perspective, which will allow for a survey of opinions and complex issues that will warrant an exploration in greater detail.

The list of variables collected from the present study will be presented to the group, and they will be asked to number them in in order of importance, thus allowing for the visualization and prioritization of the most relevant variables. It will also be possible for the group to introduce the variables that it considers necessary in the adoption of e-Government that are not in the list.

This dialogue will also allow us to highlight the most important variables and what does or does not lead to the adoption of e-Government services by citizens, so that we can present new ways or methods to make services more suitable for the population and thus improve upon adoption levels.

Our goal is that, over time, the adoption and acceptance of e-Government services will increasingly captivate more and more citizens, eventually being extended to the whole population.

\section{REFERENCES}

[1] V. P. Aggelidis and P. D. Chatzoglou, "Using a modified technology acceptance model in hospitals," International journal of medical informatics, vol. 78, pp. 115-126, 2009.

[2] S. Kim, H. J. Kim, and H. Lee, "An institutional analysis of an egovernment system for anti-corruption: The case of OPEN," Government Information Quarterly, vol. 26, pp. 42-50, 2009.

[3] S. K. Sharma and J. N. Gupta, "Building blocks of an e-government: A framework," Journal of Electronic Commerce in Organizations (JECO), vol. 1, pp. 34-48, 2003.

[4] S. K. Sharma, "Assessing e-government implementations," Electronic government, an international Journal, vol. 1, pp. 198-212, 2004.

[5] S. K. Sharma, "E-Government Services Framework," in Encyclopedia of E-Commerce, E-Government, and Mobile Commerce, ed: IGI Global, 2006, pp. 373-378.

[6] S. Jayashree and G. Marthandan, "Government to E-government to Esociety," Journal of Applied Sciences(Faisalabad), vol. 10, pp. 2205 2210, 2010.

[7] S. C. J. Palvia and S. S. Sharma, "E-government and e-governance: definitions/domain framework and status around the world," in International Conference on E-governance, 2007, pp. 1-12.

[8] CIMSA. (2017). Benefits of e-Government Available: http://www.cimsaig.com/index.php?option=com content\&view=arti cle\&id $=67 \&$ Itemid $=93 \&$ lang $=$ en

[9] Z. Ebrahim and Z. Irani, "E-government adoption: architecture and barriers," Business process management journal, vol. 11, pp. 589-611, 2005.

[10] N. Alharbi, M. Papadaki, and P. Dowland, "The impact of security and its antecedents in behaviour intention of using e-government services," Behaviour \& Information Technology, pp. 1-17, 2016.

[11] L. Carter, V. Weerakkody, B. Phillips, and Y. Dwivedi, "Citizen Adoption of E-Government Services: Exploring Citizen Perceptions of Online Services in the United States and United Kingdom," Information Systems Management, vol. 33, pp. 124-140, 2016/04/02 2016.

[12] C. Lee and U. Lei, "Adoption of e-government services in Macao," in Proceedings of the 1st international conference on Theory and practice of electronic governance, 2007, pp. 217-220.

[13] D. Israel and R. Tiwari, "Empirical study of factors influencing acceptance of e-government services in India," presented at the Proceedings of the 5th International Conference on Theory and Practice of Electronic Governance, Tallinn, Estonia, 2011.

[14] L. Carter and F. Bélanger, "The utilization of e - government services citizen trust, innovation and acceptance factors," Information systems journal, vol. 15, pp. 5-25, 2005.

[15] F. Bélanger and L. Carter, "Trust and risk in e-government adoption," The Journal of Strategic Information Systems, vol. 17, pp. 165-176, $6 / / 2008$.

[16] L. Carter and V. Weerakkody, "E-government adoption: A cultural comparison," Information Systems Frontiers, vol. 10, pp. 473-482, 2008.

[17] F. K. Chan, J. Y. Thong, V. Venkatesh, S. A. Brown, P. J. Hu, and K. Y. Tam, "Modeling citizen satisfaction with mandatory adoption of an e-government technology," 2011. 
[18] N. P. Kotamraju and T. M. van der Geest, "The tension between usercentred design and e-government services," Behaviour \& Information Technology, vol. 31, pp. 261-273, 2012.

[19] P. M. SANTOS, M. V. A. da Silva Ferreira, M. de Melo Braga, M. B. Bernardes, and A. J. Rover, "Governo eletrônico no Brasil: análise dos fatores críticos de sucesso e dos novos desafios," in JAIIO SIMPOSIO ARGENTINO DE INFORMÁTICA Y DERECHO, 2010, pp. 2045-2057.

[20] L. L. Tung and O. Rieck, "Adoption of electronic government services among business organizations in Singapore," The Journal of Strategic Information Systems, vol. 14, pp. 417-440, 2005.

[21] V. Venkatesh, F. K. Chan, and J. Y. Thong, "Designing e-government services: Key service attributes and citizens' preference structures," Journal of Operations Management, vol. 30, pp. 116-133, 2012.

[22] P. Verdegem and G. Verleye, "User-centered E-Government in practice: A comprehensive model for measuring user satisfaction," Government information quarterly, vol. 26, pp. 487-497, 2009.

23] Y.-S. Wang, "The adoption of electronic tax filing systems: an empirical study," Government Information Quarterly, vol. 20, pp. 333-352, 2003

[24] M. Warkentin, D. Gefen, P. A. Pavlou, and G. M. Rose, "Encouraging citizen adoption of e-government by building trust," Electronic markets, vol. 12, pp. 157-162, 2002.

[25] D. M. West, "E - government and the transformation of service delivery and citizen attitudes," Public administration review, vol. 64 , pp. 15-27, 2004.

[26] F. Sá, Á. Rocha, and M. P. Cota, "Dimensões preliminares para um modelo de qualidade de serviços de Governo Eletrónico Local Preliminary dimensions for a quality model of Electronic Local Government services."

[27] A. Rokhman, "e-Government adoption in developing countries; the case of Indonesia," Journal of Emerging Trends in Computing and Information Sciences, vol. 2, pp. 228-236, 2011.

[28] V. Kumar, B. Mukerji, I. Butt, and A. Persaud, "Factors for successful e-government adoption: a conceptual framework," The electronic journal of e-Government, vol. 5, pp. 63-76, 2007.

[29] K. J. Bwalya and M. Healy, "Harnessing e-government adoption in the SADC region: a conceptual underpinning," Electronic Journal of E-government, vol. 8, pp. 23-32, 2010.

[30] Z. Al-Adawi, S. Yousafzai, and J. Pallister, "Conceptual model of citizen adoption of e-government," in The Second International Conference on Innovations in Information Technology, 2005, pp. 110.

[31] É. da Silva Costa, P. de Castro, D. Silva, and A. Cappellozza, "ADOÇÃO E USO DE PORTAIS DE GOVERNO ELETRÔNICO NO AMBIENTE DO SISTEMA NACIONAL DE CIÊNCIA E TECNOLOGIA E INOVAÇÃO: UM ESTUDO BASEADO NO MODELO UTAUT," Revista Eletrônica de Ciência Administrativa, vol. 13, 2014

[32] D. Belanche, L. V. Casaló, and C. Flavián, "Integrating trust and personal values into the Technology Acceptance Model: The case of e-government services adoption," Cuadernos de Economía y Dirección de la Empresa, vol. 15, pp. 192-204, 2012.

[33] G. H. S. M. d. Moraes, "Adoção de governo eletrônico no Brasil: a perspectiva do usuário do Programa Nota Fiscal Paulista," 2014.

[34] J. P. d. C. Castro, "Aplicação do modelo UTAUT na avaliação da aceitação de um sistema integrado de gestão na área de contabilidade de uma empresa de pequeno porte," 2014

[35] S. Al-Shafi and V. Weerakkody, "Implementing free wi-fi in public parks: An empirical study in Qatar," Applied Technology Integration in Governmental Organizations: New E-Government Research: New E-Government Research, p. 201, 2010.

[36] F. Al-Sobhi, V. Weerakkody, and R. El-Haddadeh, "The relative importance of intermediaries in egovernment adoption: A study of Saudi Arabia," in International Conference on Electronic Government, 2011, pp. 62-74.

[37] L. Carter, "E-government diffusion: a comparison of adoption constructs," Transforming Government: People, Process and Policy, vol. 2, pp. 147-161, 2008

[38] L. Chiang, "Trust and security in the e-voting system," Electronic Government, an International Journal, vol. 6, pp. 343-360, 2009.
[39] S. Colesca and L. Dobrica, "Adoption and use of e-government services: the case of Romania," Journal of applied research and technology, vol. 6, pp. 204-217, 2008.

[40] W. Nasri, "Citizens' E-Government Services Adoption: An Extension of Unified Theory of Acceptance and Use of Technology Model," International Journal of Public Administration in the Digital Age (IJPADA), vol. 1, pp. 80-96, 2014.

[41] V. Venkatesh, T. A. Sykes, and S. Venkatraman, "Understanding e Government portal use in rural India: role of demographic and personality characteristics," Information Systems Journal, vol. 24, pp. 249-269, 2014

[42] J.-W. Lian, "Critical factors for cloud based e-invoice service adoption in Taiwan: An empirical study," International Journal of Information Management, vol. 35, pp. 98-109, 2015

[43] A. Baabdullah, Y. Dwivedi, and M. Williams, "Adopting an extended UTAUT2 to predict consumer adoption of M-technologies in Saudi Arabia," in UK Academy for Information Systems Conference Proceedings, 2014.

[44] M. K. Faaeq, K. Alqasa, and E. M. Al-Matari, "Technology Adoption and Innovation of E-Government in Republic of Iraq," Asian Social Science, vol. 11, p. 135, 2015.

[45] V. Venkatesh, J. Y. Thong, and X. Xu, "Consumer acceptance and use of information technology: extending the unified theory of acceptance and use of technology," 2012

[46] S. E. Colesca, "Understanding trust in e-government," Engineering Economics, vol. 63, 2015.

[47] N. L. Lu and V. T. Nguyen, "Online Tax Filing-E-Government Service Adoption Case of Vietnam," Modern Economy, vol. 7, p. 1498, 2016.

[48] N. P. Rana, Y. K. Dwivedi, M. D. Williams, and V. Weerakkody, "Investigating success of an e-government initiative: validation of an integrated IS success model," Information Systems Frontiers, vol. 17, pp. $127-142,2015$

[49] E. Abu-Shanab, "Antecedents of trust in e-government services: an empirical test in Jordan," Transforming Government: People, Process and Policy, vol. 8, pp. 480-499, 2014

[50] G. Rodrigues, J. Sarabdeen, and S. Balasubramanian, "Factors that influence consumer adoption of e-government services in the UAE: A UTAUT model perspective," Journal of Internet Commerce, vol. 15 , pp. 18-39, 2016.

[51] O. Al-Hujran, M. M. Al-Debei, A. Chatfield, and M. Migdadi, "The imperative of influencing citizen attitude toward e-government adoption and use," Computers in human Behavior, vol. 53, pp. 189 203, 2015

[52] M. Kurfal1, A. Arifoğlu, G. Tokdemir, and Y. Paçin, "Adoption of egovernment services in Turkey," Computers in Human Behavior, vol. 66, pp. 168-178, 2017.

[53] M. Z. Lallmahomed, N. Lallmahomed, and G. M. Lallmahomed, "Factors influencing the adoption of e-Government Services in Mauritius," Telematics and Informatics, 2017.

[54] M. Alshehri, S. Drew, T. Alhussain, and R. Alghamdi, "The Impact of Trust on E-Government Services Acceptance: A Study of Users' Perceptions by Applying UTAUT Model," International Journal of Technology Diffusion (IJTD), vol. 3, pp. 50-61, 2012.

[55] S. Ly and Y. C. Cho, "An Analysis of e-Government Concept and CRM in Context of e-Service Delivery," ed: Retrieved from Academia. edu: https://www. academia. edu, 2014

[56] A. A. Rabaa'i, "The use of UTAUT to investigate the adoption of egovernment in Jordan: a cultural perspective," International Journal of Business Information Systems, vol. 24, pp. 285-315, 2017.

[57] F. D. Davis, "Perceived usefulness, perceived ease of use, and user acceptance of information technology," MIS quarterly, pp. 319-340, 1989.

[58] V. Venkatesh, M. G. Morris, G. B. Davis, and F. D. Davis, "User acceptance of information technology: Toward a unified view," MIS quarterly, pp. 425-478, 2003. 